Acta vet. scand. $1977,18,451-457$.

From the Department of Obstetrics, Veterinary College of Norway,

Oslo.

\title{
PACKED CELL VOLUME (PCV) IN CONNECTION WITH UTERINE PROLAPSE AND IN PARTURIENT PARESIS IN COWS*
}

\author{
By \\ Stig Anders Ødegaard
}

\begin{abstract}
ØDEGAARD, S. A.: Packed cell volume (PCV) in connection with uterine prolapse and in parturient paresis in cows. Acta vet. scand. 1977, 18, 451 - 457. - Packed cell volume was determined in 317 cows with uterine prolapse, the condition being in more than half of these cases associated with varying degrees of hypocalcaemia, in 133 cows with parturient paresis and in 73 clinically healthy newly calved cows. Independently of each other uterine prolapse and fall in plasma calcium were associated with a significant rise in PCV. The present investigation demonstrated a marked fall in circulating blood volume in a considerable number of cows suffering from uterine prolapse. The risk of irreversible hypovolaemic shock developing in connection with uterine prolapse is not to be neglected, and may be aggravated by the simultaneous occurrence of hypocalcaemia, as several of the compensatory mechanisms are calcium dependent.
\end{abstract}

cow; packed cell volume; uterine prolapse; parturient paresis; hypovolaemic shock.

As part of an extensive clinical investigation of uterine prolapse in cows (Ødegaard 1977), it was considered of interest to determine packed cell volume (PCV). Such measurements should give an indication of the incidence and extent of major haemorrhage as well as development of shock. To the best of the author's knowledge, no systematic measurements of PCV have been carried out previously in cows suffering from uterine prolapse.

Uterine prolapse frequently occurs simultaneously with parturient paresis. In the last mentioned condition Moberg (1963), Rydberg (1969) and Lindahl et al. (1971) all found raised PCV.

* The investigation was made possible by financial support from the Agricultural Research Council of Norway. 


\section{MATERIAL AND METHODS}

The investigation involved 317 cows suffering from uterine prolapse, 133 cows with signs of parturient paresis and 73 clinically healthy cows which had calved within 24 hrs. before sampling. Quite a large number of practising veterinarians participated in the collection of the blood samples. A full description of the experimental design is given elsewhere (Ødegaard 1977).

Blood samples were taken from the jugular vein using heparinized vacutainers, and sent as quickly as possible to the Department of Obstetrics, Veterinary College of Norway. PCV was determined by centrifugation for $5 \mathrm{~min}$. at $12,000 \times \mathrm{g}$ in a 'Cellokrit 2' centrifuge (AB Lars Ljungberg \& Co., Stockholm, Sweden).

Plasma for calcium determination was stored at $-20^{\circ} \mathrm{C}$ for up to five months and analysed by autoanalyser as described by Halse (1968).

Data were processed by computer at the Centre for Experimental Design and Data Processing*.

\section{RESULTS}

The mean PCV for 317 cows suffering from uterine prolapse was 42.6. For 133 cows with parturient paresis and 73 clinically healthy, newly calved cows the corresponding figures were 43.3 and 38.0. PCV in clinically healthy cows was significantly lower than in the other two categories $(P<0.001$, Table 1$)$.

Ta b le 1. Packed cell volume in cows with uterine prolapse, cows suffering from parturient paresis and in clinically healthy cows which had calved within 24 hrs. of sampling.

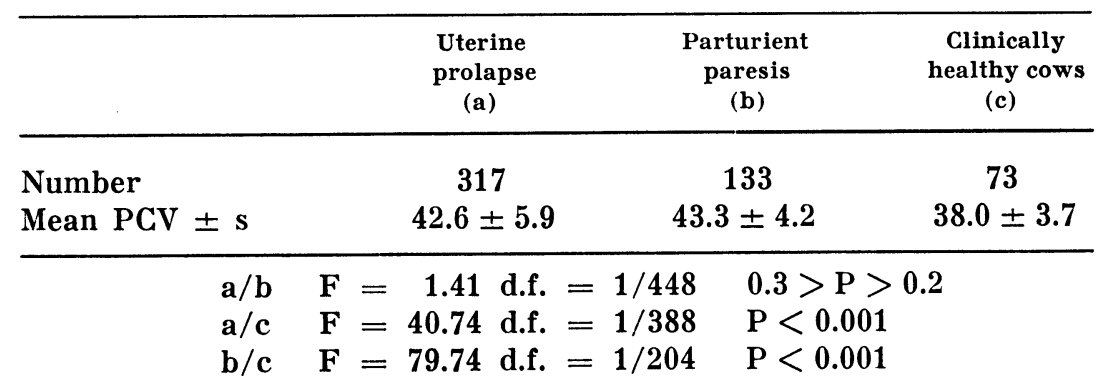

Table 2 shows PCV in relation to plasma calcium levels in cows with uterine prolapse and a control group consisting of

* Address: 1432 Ås-NLH, Norway. 
T a b l e 2. Packed cell volume in relation to plasma calcium level in 311 cows with uterine prolapse and in a group consisting of 133 cows with parturient paresis and 73 clinically healthy newly calved cows.

\begin{tabular}{lccc}
\hline & \multicolumn{3}{c}{ Plasma calcium, mg/100 ml } \\
\cline { 2 - 4 } & $\leqq 6.0$ & $6.1-8.0$ & $>8.0$ \\
\hline $\begin{array}{l}\text { Uterine prolapse } \\
\text { Number }\end{array}$ & 106 & & \\
$\quad$ Mean PGV $\pm \mathrm{s}$ & $45.0 \pm 5.5$ & $41.6 \pm 6.1$ & $41.3 \pm 5.7$ \\
\hline No uterine prolapse & & & 126 \\
$\quad \begin{array}{l}\text { Number } \\
\text { Mean PGV } \pm \mathrm{s}\end{array}$ & 82 & 52 & 72 \\
\hline
\end{tabular}

Two-way analysis of variance:

Prolapse/control $\quad F=9.57$ d.f. $=1 / 513 \quad \mathrm{P}<0.005$

Plasma calcium levels $\quad F=33.51$ d.f. $=2 / 513 \quad P<0.001$

Interaction prolapse/plasma calcium

$$
\mathrm{F}=2.77 \text { d.f. }=2 / 511 \quad \mathrm{P}>0.05
$$

cows suffering from parturient paresis as well as clinically healthy cows. Both in the group of uterine prolapse and the control group, there was a rise in PCV with decreasing levels of plasma calcium. Two way analysis of variance showed that uterine prolapse resulted in a significant increase in PCV, independent of plasma calcium ( $\mathrm{P}<0.005)$, and that a decrease in plasma calcium levels was associated with raised $P C V$ values $(P<0.001)$. The difference in PCV between prolapse cows and control cows was 2.7 when plasma calcium was $>8.0 \mathrm{mg} / 100 \mathrm{ml}$, and 1.2 when plasma calcium was $\leqq 6.0 \mathrm{mg} / 100 \mathrm{ml}$, the highest values being found in the prolapse cows. At plasma calcium levels of $6.1-8.0$ $\mathrm{mg} / 100 \mathrm{ml}$, the mean values in the two groups were nearly identical (Table 2). The variations in difference between cows with and without prolapse at the different plasma calcium levels were not significant.

In Table 3 is illustrated the changes in mean PCV and plasma calcium in cows suffering from parturient paresis with or without uterine prolapse and selected by the criterion of increased plasma calcium from first to second calcium treatment. PCV decreased significantly between treatments only in the group suffering from both parturient paresis and uterine prolapse.

Two cows with parturient paresis alone and six with parturient paresis associated with uterine prolapse showed a numeri- 
T a b le 3. Packed cell volume and plasma calcium in 14 cows with uterine prolapse and parturient paresis and in 14 cows with parturient paresis. All cows needed more than one calcium treatment and had a rise in plasma calcium from first to second treatment.

\begin{tabular}{llccl}
\hline & & $\begin{array}{c}\text { First } \\
\text { treatment }\end{array}$ & $\begin{array}{c}\text { Second } \\
\text { treatment }\end{array}$ & \\
\hline $\begin{array}{l}\text { Uterine } \\
\text { prolapse } \\
\text { associated } \\
\text { with }\end{array}$ & mean PCV $\pm \mathrm{s}$ & $45.1 \pm 6.1$ & $39.9 \pm 2.9$ & $\mathrm{P}<0.01$ \\
$\begin{array}{l}\text { parturient } \\
\text { paresis }\end{array}$ & $\begin{array}{l}\text { mean plasma } \\
\text { calcium } \pm \mathrm{s}\end{array}$ & $4.17 \pm 0.88$ & $6.47 \pm 1.58$ & $\mathrm{P}<0.001$ \\
\hline $\begin{array}{l}\text { Parturient } \\
\text { paresis }\end{array}$ & $\begin{array}{l}\text { mean PCV } \pm \mathrm{s} \\
\text { mean plasma } \\
\text { cialcium } \pm \mathrm{s}\end{array}$ & $44.4 \pm 3.8$ & $42.4 \pm 3.2$ & $\mathrm{P}>0.05$ \\
\hline
\end{tabular}

cal fall in plasma calcium from first to second treatment. A normalization of PCV took place also in these cases, and in the prolapse cows the decrease was significant $(P<0.05)$.

\section{DISCUSSION}

A large variation exists in the degree to which uterine prolapse affects the well-being of the cow. In many cases the cow seems to be astonishingly little affected, whereas, in some cases death rapidly occurs. Some of these fatalities are due to rupture of blood vessels and haemorrhagic shock, while in other cases other types of shock probably develop. It thus seemed appropriate to examine whether systematic PCV measurement could be a tool in assessing the risk for shock in cows with uterine prolapse. As this condition is often associated with parturient paresis, it was also deemed of interest to investigate changes in PCV in cases of hypocalcaemia.

In accordance with previous studies on parturient paresis, the present study has demonstrated a significant relationship between PCV and plasma calcium in hypocalcaemic cows. Although other possibilities exist the observed relationship between PCV and calcium is probably one of cause and effect. This hypothesis is supported by the fact that Daniel (personal communication 1976) after Na-EDTA infusions found a rise in PCV of a magnitude similiar to that found in the present study. 
No experimental data exist that can adequately explain the observed haemoconcentration with falling plasma calcium. Previously cited authors regard it as being an expression of general dehydration. Although such a possibility cannot be ruled out as long as measurements of the different fluid compartments have not been carried out, the acute nature of parturient paresis speaks against such a hypothesis in the author's opinion. It is more likely that the effects of calcium on the heart, the vascular smooth muscle, striated muscle and possibly on capillary permeability favour transfer of fluid into the tissues. Although several factors affect the balance of exchange between the circulatory system and the extracellular fluid, it is relevant to mention that Daniel (personal communication) found an increase in venous pressure from 4 to $17 \mathrm{~mm} \mathrm{Hg}$ by reducing plasma calcium to half the normal value. The two cows with parturient paresis which showed a slight fall in plasma calcium from first to second treatment, and at the same time also a fall in PCV, do not, however, fit into such a hypothesis. As regards the six cows with uterine prolapse in which the situation concerning changes in calcium and PCV between treatments was the same, any blood loss in connection with the prolapse would have been compensated by transfer of fluid to the vascular system bringing about a reduction in PCV, as well as the effect of the prolapse being no longer present.

Independent of the concomitant changes in calcium concentration uterine prolapse also seemed to affect PCV. Haemoconcentration as a result of uterine prolapse is probably completely or partly due to the considerable circulatory disturbances which often arise in the organ. Nor can it be excluded that nervous impulses generated in the everted uterus might induce general vasodilatation and low-resistance shock. A certain significance can also possibly be attributed to changes in intra-abdominal pressure.

In some cows with uterine prolapse extremely high PCV values were found, whilst, on the other hand, some cows had subnormal values. Many of the cows with low PCV had plasma calcium between 6.1 and $8.0 \mathrm{mg} / 100 \mathrm{ml}$. The standard deviation was largest in this group. This explains why the mean PCV for this group approached the value for cows with higher plasma calcium levels, and further did not differ from the PCV found in cows with parturient paresis and plasma calcium $6.1-8.0 \mathrm{mg} /$ $100 \mathrm{ml}$. 
Several factors will certainly to a variable and unknown degree affect the values for PCV in cows suffering from uterine prolapse and impair the interpretation of the data obtained. 1) Many of the cows were sampled at a time when blood loss would probably only to a slight extent have been compensated by fluid transfer to the circulatory system, a mechanism that would tend to reduce PCV. 2) The general tendency to haemoconcentration caused by the prolapse will mask, or at least reduce, the fall in PCV that blood loss would otherwise have brought about. 3) The true hypovolaemia will also be more pronounced than suggested by the haemoconcentration, as blood loss of varying degree will bring about a reduction in volume. Depending on the degree to which this blood loss has been compensated it will to a varying extent influence the changes in PCV that uterine prolapse by itself causes. 4) The PCV material includes relatively fewer cows that died suddenly than the total prolapse material, because some cows were found dead, or died before the veterinarian arrived on the spot. However, a significantly higher mortality was found in cows with $\mathrm{PCV} \leqq 35$ or $>50$ as compared with the rest of the material (Ødegaard 1977).

The increase in PCV from 38.6 in cows without uterine prolapse and with plasma calcium $>8.0 \mathrm{mg} / 100 \mathrm{ml}$, to 45.0 in prolapse cows with plasma calcium $\leqq 6.0 \mathrm{mg} / 100 \mathrm{ml}$ corresponds to a reduction in blood volume of almost $15 \%$ and a plasma reduction of $23 \%$. Considering that these are average figures and bearing in mind the aspects mentioned above it is evident that there is a pronounced reduction in circulating blood volume in a considerable number of cows with uterine prolapse. Development of irreversible hypovolaemic shock may also be aggravated by a simultaneous hypocalcaemia, since several of the compensatory mechanisms such as contraction of blood vessels and release of catecholamines, corticoids and vasopressin are calcium dependent.

\section{REFERENCES}

Halse, $K .:$ Automated photometric estimation of blood calcium. Liberation of zinc by calcium from Zn-EGTA in the presence of a zinc indicator. In E. Kawerau (ed.): Automation in Analytical Chemistry. Technicon symposia 1967, Vol. II, pp. 143-150. Mediad Inc. White Plains, N. Y. 1968.

Lindahl, O., L. Ekman, B. Gustafsson \& L.-E. Edqvist: Kliniska och blodkemiska data vid puerperal pares. (Clinical and blood- 
chemical data in parturient paresis). Svensk Vet.-Tidn. 1971, $23,171-175$.

Moberg, R.: Die hämatologischen Befunde bei der Gebärparese. (Haematological findings in parturient paresis). Proc. 17th Int. vet. Congr., Hannover 1963.

Rydberg, C.: Hämatologische und blutchemische Untersuchungen von klinisch gesunden sowie an primärer Ketose und puerperaler Parese erkrankten Rinden. (Haematological and blood-chemical investigations in clinically healthy cows as well as cows suffering from primary ketosis and parturient paresis). Acta vet. scand. 1969, Suppl. 27.

Ødegaard, $S$. A.: Uterine prolapse in dairy cows. A clinical study with special reference to incidence, recovery and subsequent fertility. Acta vet. scand. 1977. Suppl. 63.

\section{SAMMENDRAG}

Hematokrit $i$ forbindelse med uterusprolaps og ved puerperal parese hos $k u$.

Hematokrit er bestemt hos 317 kyr med uterusprolaps som i mer enn halvparten av tilfellene var kombinert med varierende grad av hypokalsemi, $133 \mathrm{kyr}$ med puerperal parese og 73 klinisk friske nybære kyr. Uterusprolaps og senkning i plasmakalsiumnivå var uafhengig av hverandre fulgt av en signifikant stigning i PCV.

Unders $\varnothing$ kelsen viser at det hos et betydelig antall kyr med uterusprolaps foreligger en uttalt reduksjon av sirkulerende blodvolum. Fare for utvikling av et irreversibelt hypovolemisk sjokk $\mathrm{i}$ forbindelse med uterusprolaps er betydelig, og kan synes å være forøket ved samtidig hypokalsemi, siden flere av de kompensatoriske reaksjoner er kalsiumavhengige.

\section{(Received May 23, 1977).}

Reprints may be requested from: Stig Anders Ødegaard, the Department of Pharmacology and Toxicology, Veterinary College of Norway, Postboks 8146, Oslo Dep., Oslo 1. 